\title{
Aplikasi Identifikasi Citra Telur Ayam Omega-3 Dengan Metode Segmentasi Region Of Interest Berbasis Android
}

\author{
Ahmad Muzami $^{1)}$, Oky Dwi Nurhayati ${ }^{2)}$, Kurniawan Teguh Martono ${ }^{2)}$ \\ Program Studi Sistem Komputer, Fakultas Teknik, Universitas Diponegoro \\ Jalan Prof. Sudharto, Tembalang, Semarang, Indonesia
}

\begin{abstract}
Abstrak - Telur ayam merupakan sumber protein hewani kedua setelah ikan. Harga telur yang terjangkau dan bernilai gizi tinggi menjadikan telur salah satu bahan makanan yang sering dikonsumsi oleh masyarakat. Namun sekarang telah muncul telur hasil rekayasa yang memiliki nilai gizi yang lebih tinggi, yaitu telur yang mengandung omega-3. Bagian yang membedakan telur biasa dengan telur omega-3 adalah kuning telur omega-3 agak kemerahan sementara kuning telur biasa berwarna kuning.

Tujuan dari penelitian ini adalah untuk menghasilkan perangkat lunak yang dapat mengidentifikasi secara visual jenis telur biasa atau telur omega-3. Pendeteksian jenis telur dilakukan dengan menggunakan pencocokan tekstur cangkang telur berdasarkan data penelitian.

Penelitian menghasilkan luaran metode atau algoritma untuk untuk identifikasi citra digital dengan metode pra-pengolahan, segmentasi region of interest, serta analisis tekstur citra menggunakan metode statistik orde pertama nilai mean dan standard deviasi. Hasil dari penelitian menujukkan bahwa aplikasi Deteksi Citra Telur Omega-3 dapat membedakan citra telur ayam biasa atau citra telur ayam omega-3.
\end{abstract}

Kata Kunci : telur ayam omega-3, region of interest, mean, standar deviasi, Android, OpenCV

\section{PENDAHULUAN}

$\mathrm{S}$ alah satu bahan makanan yang diminati oleh masyarakat Indonesia adalah telur ayam, disamping harganya yang terjangkau juga mudah untuk mendapatkan telur ayam di toko-toko atau warung sembako. Telur ayam yang biasa dikonsumsi berasal dari ayam petelur, bukan ras ayam kampung. Selain dua jenis telur tersebut ada juga telur ayam yang mengandung omega-3. Telur ayam omega-3 merupakan telur yang dihasilkan dari ayam petelur dimana induknya diberikan pakan yang mengandung suplemen omega-3 selama tiga munggu berturutturut. Suplemen omega-3 dapat dibuat melalui proses pengemulsian dan dispersi dari bahan limbah perebusan ikan sarden. Telur ayam omega3 memiliki kandungan Decosahexaenoic Acid atau DHA yang merupakan suatu asam lemak yang sangat diperlukan oleh tubuh daintaranya untuk meningkatkan kecerdasan otak anak, mencegah penyakit jantung koroner serta meningkatkan daya tahan tubuh. Kelebihan lain dari telur ini adalah terdapat kandungan lemat tak jenuh yang mampu menurunkan kadar kolesterol.

Secara visual telur ayam biasa dengan telur ayam omega-3 terlihat sama karena memang samasama dihasilkan dari ras ayam petelur, hanya berbeda pakan dari induknya saja. Selama ini cara membedakan telur ayam biasa dan telur ayam omega-3 hanya bisa diketahui melalui kuning telurnya saja. Jika dipecah kuning telur yang mengandung omega-3 berwarna kemerahan sementara kuning telur pada telur biasa berwarna kuning.

Aplikasi identifikasi telur ayam omega-3 diharapkan mampu mengidentifikasi secara otomatis citra digital telur ayam untuk membedakan jenis citra telur ayam yang mengandung omega-3 dan telur ayam biasa. Teknik pengolahan citra mampu untuk melakukan proses identifikasi seperti yang dilakukan oleh ahli berdasarkan parameter-parameter visual. Saat ini kemampuan perangkat telepon pintar yang ada di pasaran sudah memadai untuk proses pengambilan data citra dengan kamera resolusi tinggi melalui fasilitas pemrograman android. Aplikasi ini dibuat menggunakan bahasa pemrograman Java yang terintegrasi dengan Android SDK, Eclipse, serta library OpenCV. Dengan menggunakan metode pra-pengolahan dan segmentasi Region of Interest sehingga nantinya sistem dapat mengidentifikasi telur dengan baik. Untuk menghindari pembahasan yang meluas maka dalam tugas akhir ini ditetapkan batasan-batasan masalah dengan hal-hal sebagai berikut :

1. Pengujian dilakukan pada telur ayam biasa dan telur ayam yang mengandung omega-3.

2. Perancangan aplikasi Deteksi Telur Ayam Omega-3 menggunakan metode segementasi region of interest.

3. Aplikasi yang dihasilkan akan berjalan pada sistem operasi Android, dengan versi OS minimum Android 2.3 (Gingerbread). 
4. Pengembangan aplikasi menggunakan perangkat lunak Eclipse 4.2 serta menggunakan library OpenCV 2.4.9.

\section{DASAR TEORI}

\section{A. Telur Ayam}

Telur merupakan produk peternakan yang memberikan sumbangan terbesar bagi tercapainya kecukupan gizi masyarakat. Dari sebutir telur didapatkan gizi yang cukup sempurna karena mengandung zat-zat gizi yang sangat baik \& mudah dicerna. Oleh karenanya telur merupakan bahan pangan yang sangat baik untuk anakanak yang sedang tumbuh dan memerlukan protein dan mineral dalam jumlah banyak dan juga dianjurkan diberikan kepada orang yang sedang sakit untuk mempercepat proses kesembuhannya $^{[1]}$.

Kandungan protein yang ada dalam telur ayam sangat mirip dengan kandungan pada telur angsa, telur puyuh maupun jenis telur lainnya. Tabel kandungan gizi telur ditunjukkan pada tabel 1 .

Tabel 1 Kandungan gizi dari beberapa telur

\begin{tabular}{|c|c|c|c|c|c|c|}
\hline No. & $\begin{array}{l}\text { Zat } \\
\text { Gizi }\end{array}$ & Ayam & $\begin{array}{l}\text { Itik } \\
\text { 1) }\end{array}$ & $\begin{array}{l}\text { Puy } \\
\text { uh 1) }\end{array}$ & $\begin{array}{l}\text { Kalku } \\
\text { n }^{2)}\end{array}$ & Angsa \\
\hline 1. & Air, $g$ & 72.9 & 70.1 & 72.6 & 72.5 & 70.43 \\
\hline 2. & $\begin{array}{l}\text { Kalori, } \\
\text { gkal }\end{array}$ & 159 & 183 & 168 & 171 & 185 \\
\hline 3. & $\begin{array}{l}\text { Protein } \\
, \mathrm{g}\end{array}$ & 13.2 & 12.6 & 12.4 & 13.68 & 13.87 \\
\hline 4. & $\begin{array}{l}\text { Lemak, } \\
\mathrm{g}\end{array}$ & 11.1 & 13.6 & 12.4 & 11.88 & 13.27 \\
\hline 5. & $\begin{array}{l}\text { Karboh } \\
\text { idrat, g }\end{array}$ & 1.5 & 2.5 & 1.6 & 1.15 & 1.35 \\
\hline 6. & Abu, g & 1.3 & 1.2 & 1.0 & 0.79 & 1.08 \\
\hline 7. & $\mathrm{Ca}, \mathrm{mg}$ & 56 & 62 & 68 & - & - \\
\hline 8. & $\mathrm{P}, \mathrm{mg}$ & 200 & 206 & 203 & - & - \\
\hline 9. & $\mathrm{Fe}, \mathrm{mg}$ & 2.8 & 3.2 & 2.9 & - & - \\
\hline
\end{tabular}

\section{B. Telur Ayam Omega-3}

Omega-3 adalah Jenis lemak tak jenuh, atau lemak sehat diamana omega-3 dapat melindungi kesehatan jantung. Omega-3 sangat penting untuk kesehatan tubuh, sayangnya tubuh manusian tidak dapat memproduksi omega-3 secara alami dan sebagai gantinya perlu untuk mengonsumsi makanan seperti ikan salmon, beberapa jenis minyak, kacang-kacangan, maupun telur omega$3^{[2]}$.

Pemanfaatan limbah organik sebagai bahan baku suplemen merupakan terobosan teknologi dalam aplikasi peningkatan kualitas produk ternak ayam. Berbagai limbah telah digunakan para peneliti untuk merekayasa produk telur. Diantara limbah yang ramah lingkungan tersebut dan masih mempunyai gizi baik yaitu minyak yang diperoleh dari limbah perebusan ikan sarden, yang merupakan sumber asam lemak tidak jenuh
(PUFA) omega-3, omega-6 dan omega-9. Limbah ampas tahu digunakan sebagai filler pada pembuatan Suplemen omega- $3^{[3]}$.

\section{Ekualisasi Histogram}

Histogram citra adalah grafik yang menggambarkan penyebaran nilai-nilai intensitas pixel dari suatu citra atau bagian tertentu di dalam citra. Dari sebuah histogram dapat diketahui frekuensi kemunculan nisbi (relatif) dari intensitas pada citra tersebut. Histogram juga dapat menunjukkan banyak hal tentang kecerahan dan kontas dari sebuah gambar ${ }^{[4]}$.

Citra yang memiliki kontras terlalu terang atau terlalu gelap memiliki histogram yang sempit. Histogram nya hanya terlihat menggunakan setengah dari daerah derajat keabuan. Citra yang baik memiliki histogram yang mengisi daerah derajat keabuan secara penuh dengan distribusi yang merata pada setiap derajat keabuan pixe ${ }^{[5]}$.

\section{Region Of Interest (ROI)}

Region of interest (ROI) pada penelitian ini adalah daerah tertentu pada citra digital yang diseleksi dan pada daerah yang diseleksi tersebut akan dilakukan proses analisis tekstur citra.

Region of Interest (ROI) merupakan salah satu proses pengolahan citra dimana pengguna mampu mengolah citra yang mengandung informasi data citra yang dikehendaki ${ }^{[6]}$. ROI bekerja dalam pengkodean secara berbeda pada area tertentu dari citra digital, sehingga area tertentu tersebut memiliki kualitas yang lebih baik dari area sekitarnya. Proses ini sangat penting bila terdapat area tertentu dari citra yang dirasa lebih penting dari bagian lainnya. Area penting tersebut selanjutnya dapat digunakan untuk pengolahan dengan metode tertentu sesuai dengan keperluan penggunaan. Pada beberapa aplikasi pemilihan area tersebut dapat dilakukan dengan fitur selection tools dengan bentuk-bentuk tertentu seperti persegi, oval, segi bebas, bentuk bebas.

\section{E. Ekstraksi Ciri Statistik}

Ekstraksi ciri merupakan tahap awal dari klasifikasi dan interpretasi citra. Ekstraksi ciri yang sering digunakan adalah ekstraksi ciri statistik orde pertama dan ekstraksi ciri orde kedua. Ekstraksi ciri statistik orde pertama dilakukan melalui histogram citra yang bersangkutan (histogram menunjukkan nilai derajat keabuan/intensitas piksel dari suatu citra). Sedangkan ekstraksi ciri statitik orde kedua dilakukan dengan menggunakan matriks kookurensi, yaitu matriks yang merepresentasikan hubungan ketetanggaan antar piksel dalam suatu citra pada berbagai orientasi dan jarak spasial.

Ekstraksi ciri orde pertama merupakan metode pengambilan ciri yang berdasarkan pada histogram citra. Histogram merupakan probabilitas 
kemunculan derajat keabuan piksel pada suatu citra $^{[7]}$. Bila $i$ menyatakan tingkat keabuan pada suatu citra maka probabilitas dari $i$ dinyatakan seperti persamaan (1)

$$
h_{i}=\frac{n_{i}}{n}
$$

hi $=$ nilai histogram

ni $=$ jumlah piksel yang muncul pada intensitas keabuan

$$
\text { ke-i }
$$

$\mathrm{n}=$ jumlah keseluruhan piksel pada area

Dari nilai-nilai histogram yang dihasilkan, dapat dihitung beberpa parameter yang ciri statistik orde pertama, antara lain :

\section{Mean $(\mu)$}

Menunjukkan ukuran disperse dari suatu citra seperti ditunjukkan pada persamaan (2).

$$
\mu=\sum_{n} f_{n} p\left(f_{n}\right)
$$

dimana :

$$
\begin{array}{ll}
f_{n} & =\text { nilai intensitas keabuan } \\
\mathrm{p}\left(\mathrm{f}_{\mathrm{n}}\right) & =\text { nilai histogram }
\end{array}
$$

2. Standar Deviasi $(\sigma)$

Standar Deviasi adalah salah satu teknik statistik yang digunakan untuk menjelaskan homognitas kelompok yang ditunjukkan seperti persamaan (3).

$$
\sigma=\sqrt{\sum_{n=0}^{N}\left(f_{n}-\mu\right)^{2} p\left(f_{n}\right)}
$$

dimana :

$$
\begin{array}{ll}
\sigma & =\text { nilai standar deviasi } \\
\mathrm{f}_{\mathrm{n}} & =\text { nilai intensitas keabuan } \\
\mathrm{p}\left(\mathrm{f}_{\mathrm{n}}\right) & =\text { nilai histogram } \\
\mu & =\text { nilai mean }
\end{array}
$$

\section{F. Open Computer Vision (OpenCV)}

OpenCV adalah sebuah library yang berisi fungsi-fungsi pemrograman untuk teknologi computer vision. OpenCV bersifat open source, bebas digunakan untuk keperluan akademis maupun kepentingan komersial. Di dalam OpenCV terdapat interface untuk $\mathrm{C}++, \mathrm{C}$, Python, dan java yang dapat berjalan pada sistem operasi Windows, Linux, Android, dan Mac. Pada awalnya library opencv ditulis dalam bahasa pemrograman $\mathrm{C}$, namun sejak versi 2.0, pada opencv tersedia dalam interface $\mathrm{C}$ dan interface $\mathrm{C}++$.

Pengguanaan OpenCV sebagai library untuk aplikasi pengolahan citra sudah banyak digunakan, salah satunya adalah penelitian yang dilakukan oleh Oktaviani $(2014)^{[8]}$ dengan membuat aplikasi mobile untuk mengidentifikasi fertilitas telur itik melalui citra telur itik. Metode yang digunakan pada penelitian tersebut adalah transformasi citra RGB kedalam citra keabuan dan thresholding. Sedangkan penelitian lain dilakukan oleh Yulianto (2008) yang bertujuan untuk meningkatkan Citra untuk memperjelas foto CTscan otak. Pada penelitian ini Yulianto (2008) menggunakan beberapa metode pengolahan citra antara lain ekualisasi histogram, perentangan kontras, histogram classify, dan region of interest.

\section{PERANCANGAN Sistem}

Perancangan sistem aplikasi perangkat bergerak dibutuhkan tahap prosedur pengembangan perangkat lunak. Berikut adalah tahap-tahap perancangan diagram alir pada aplikasi identifikasi citra telur ayam omega-3 dengan metode segmentasi region of interest.

A. Kebutuhan Sistem

1. Perangkat Lunak

- $\quad$ Sistem Operasi Windows 7 64-bit.

- $\quad$ Eclipse Juno.

- $\quad$ OpenCV 2.4.9.

- $\quad$ Microsoft Office Word 2010.

- $\quad$ Sistem Operasi Android OS v4.4.4 (KitKat).

- $\quad$ Fiji ImageJ.

2. Perangkat Keras

- Laptop ASUS A43SA, Prosesor Intel® Core $^{\mathrm{TM}}$ i3-2330 (2.20 GHz, 3M Cache), RAM 4GB.

- $\quad$ Smartphone Xiaomi Redmi 2 Prime, 4,7 Inch.

\section{B. Prosedur Pengembangan Program}

Pada tahap ini dalam melakukan perancangan program mengunakan metode pengembangan waterfall dan diagram alir program. Berikut adalah metode pengembangan program yang digunakan dalam aplikasi ini :

1. Metode Pengembangan Waterfall

Dalam tahap perancangan sistem ini digunakan metode pengembangan perangkat lunak waterfall. Tahap-tahap pada metode pengembangan waterfall dimulai dari analisis kebutuhan, desain sistem dan perangkat lunak, Implementasi dan pengujian unit, integrasi dan pengujian sistem, serta pemeliharaan.

2. Perancangan Diagram Alir Program

Diagram alir program merupakan gambaran umum bagaimana aplikasi identifikasi telur omega3 ini berjalan. Proses jalannya aplikasi secara runtun dapat digambarkan menjadi diagram alir program seperti pada gambar 1 .

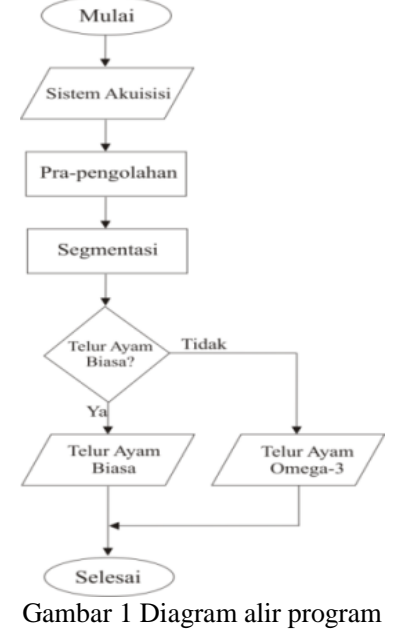

Pada diagram alir program di atas menunjukkan tahapan-tahapan yang dilakukan oleh 
aplikasi. Tahapan pertama adalah sistem akuisisi, merupakan tahap pengambilan citra digital telur ayam yang akan digunakan dalam aplikasi. Setelah didapat citra telur ayam yang akan diolah tahap selanjutnya adalah tahap pra-pengolahan. Tahap ini merupakan tahap untuk memperbaiki kualitas citra yang akan diolah. Tahap pra-pengolahan ini menggunakan filter median dan histogram ekualisasi. Citra yang sudah diperbaiki kualitasnya kemudian akan diolah menggunakan metode segmentasi region of interest (ROI). Citra uji yang sudah disegmentasi kemudian akan diklasifikasi untuk menentukan apakah citra telur ayam tersebut merupakan telur ayam biasa atau telur ayam omega-3.

\section{Perancangan Antarmuka Perangkat Lunak}

Perancangan antarmuka atau tampilan diperlukan untuk memberikan penjelasan dari fungsi-fungsi yang dilakukan sistem. Perancangan ini memuat isi dari tiap halaman yang ditampilkan seperti tombol, teks, dan gambar. Perancangan antarmuka bertujuan untuk memberikan nilai tambah pada aplikasi serta mempermudah pengguna dalam penggunaan.

1. Antarmuka Halaman Utama

Halaman utama aplikasi merupakan rancangan tampilan untuk halaman awal setelah aplikasi dijalankan seperti ditunjukkan pada Gambar 2.

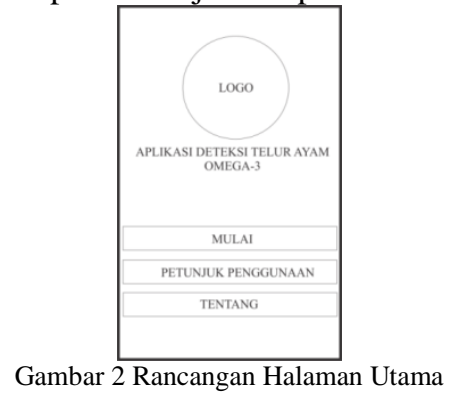

2. Antarmuka Halaman Unggah Citra

Halaman ini menunjukkan rancangan antarmuka dari proses pengunggahan citra sampel yang akan diproses, seperti ditunjukkan pada Gambar 4.

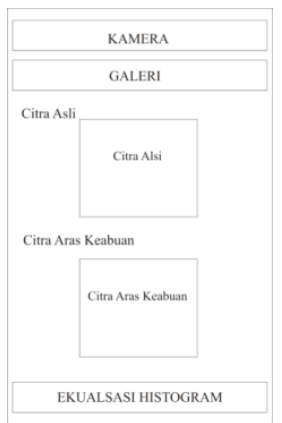

Gambar 3 Tampilan halaman unggah citra

3. Antarmuka Halaman Ekualisasi Histogram
Halaman ini berisi rancangan tampilan untuk menunjukkan citra hasil ekualisasi histogram, seperti ditunjukkan pada Gambar 4.

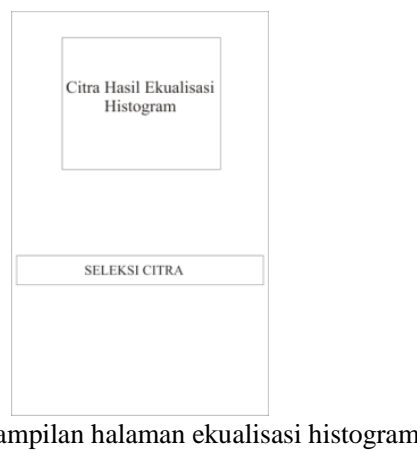

4. Antarmuka Halaman ROI

Halaman ini hanya berisi rancangan tampilan gambar yang akan diproses menggunakan region of interest (ROI) seperti ditunjukkan pada gambar 5.

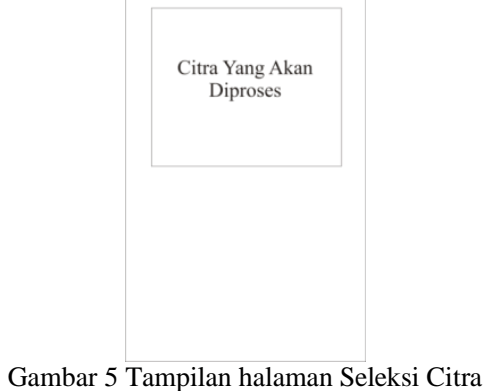

5. Antarmuka Halaman Analisis Citra

Halaman ini berisi rancangan tampilan dari citra hasil seleksi region of interest serta nilai analisis citra, seperti yang ditunjukkan pada Gambar 6.

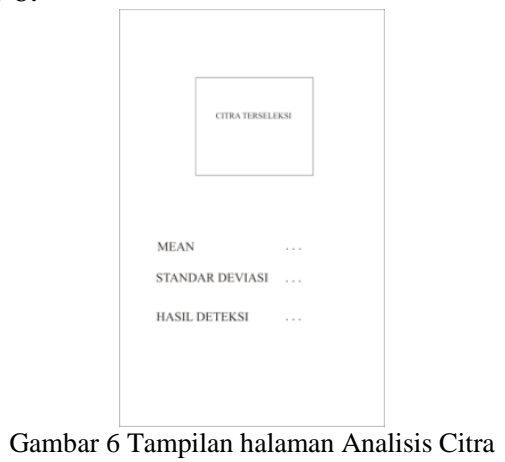

6. Halaman Petunjuk Penggunaan

Halaman ini berisi rancangan tampilan informasi mengenai langkah-langkah penggunaan aplikasi pendeteksi citra telur ayam omega-3 seperti yang ditunjukkan pada Gambar 7. 


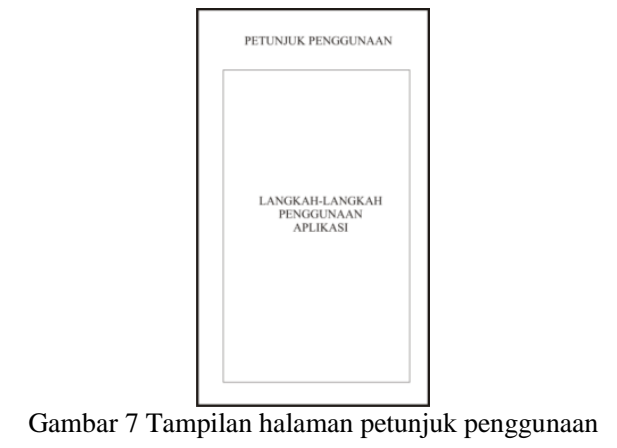

7. Halaman Tentang

Halaman ini berisi rancangan tampilan mengenai informasi yang berkaitan dengan aplikasi pendeteksi citra telur ayam omega-3 seperti yang ditunjukkan pada Gambar 8.

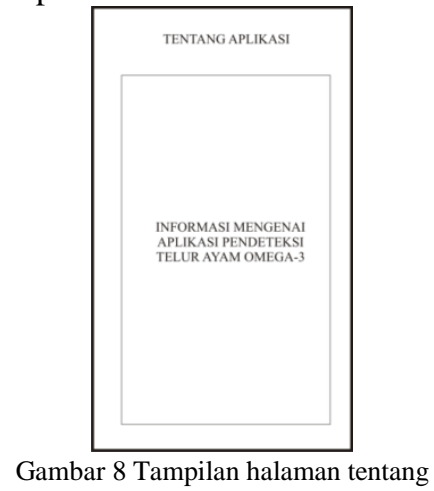

\section{IMPLEMENTASI DAN PENGUJIAN}

A. Implementasi Antarmuka Aplikasi

1. Halaman Utama Aplikasi

Merupakan halaman awal mulai ketika aplikasi mulai dijalankan. Tampilan ditunjukkan pada gambar 9 .

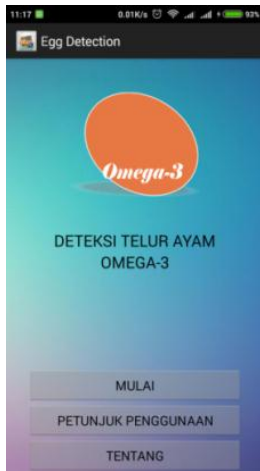

Gambar 9 Halaman utama aplikas

\section{Halaman Unggah Citra}

Merupakan halaman yang terdiri dari tiga tombol yaitu Kamera, Galeri dan Ekualisasi Histogram. Tampilan ditunjukkan pada gambar 10 .

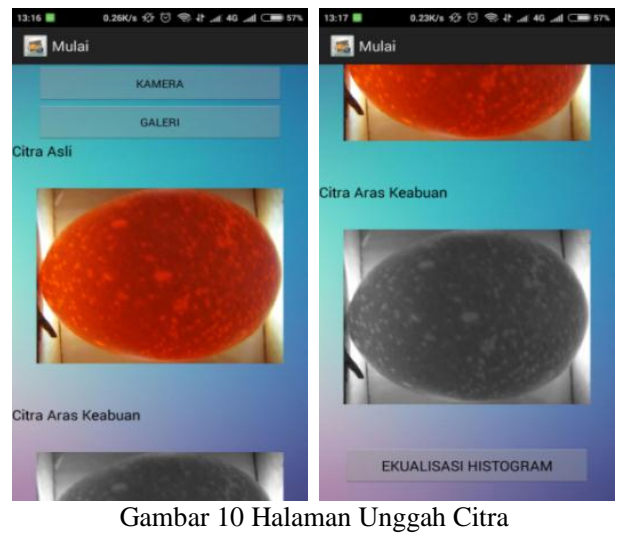

3. Halaman Ekualisasi Histogram

Merupakan halaman yang terdiri dari tampilan citra aras keabuan yang sudah mendapatkan proses ekualisasi histogram dan filter median, serta terdiri dari tombol Seleksi Citra. Tampilan halaman Ekualisasi Histogram ditunjukkan pada gambar 11 .

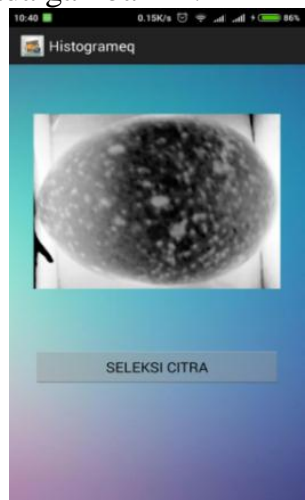

Gambar 11 Halaman Ekualisasi Histogram

\section{Halaman Seleksi Citra}

Merupakan halaman yang menampilkan proses seleksi citra area kuning telur. Proses seleksi ditandai dengan garis patah-patah berwarna putih seperti pada gambar 12.

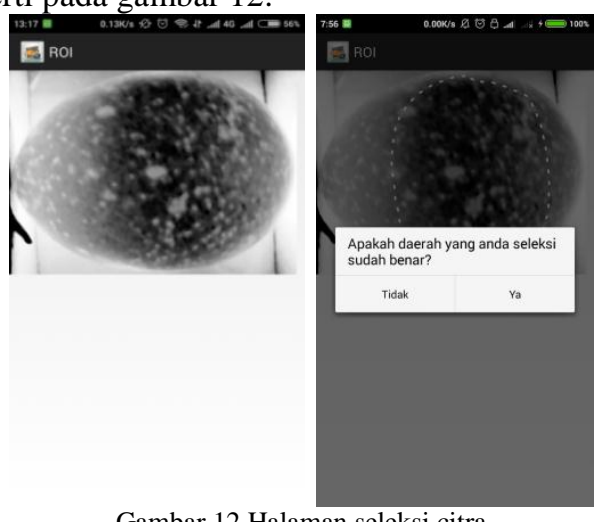

Gambar 12 Halaman seleksi citra

\section{Halaman Analisis Citra}

Halaman analisis citra merupakan halaman ditampilkannya citra terseleksi, nilai statistika mean dan standar deviasi, serta hasil akhir identifikasi seperti pada gambar 13 . 


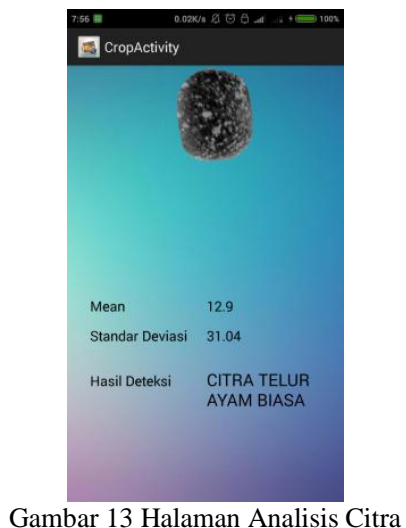

6. Halaman Petunjuk

Merupakan halaman petunjuk penggunaan aplikasi. Tampilan ditunjukkan pada gambar 14.

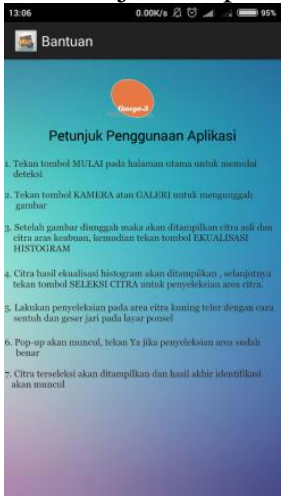

Gambar 14 halaman Petunjuk Penggunaan

6. Halaman Tentang

Merupakan halaman profil dari pengembang dan versi aplikasi. Tampilan ditunjukkan pada gambar 15.

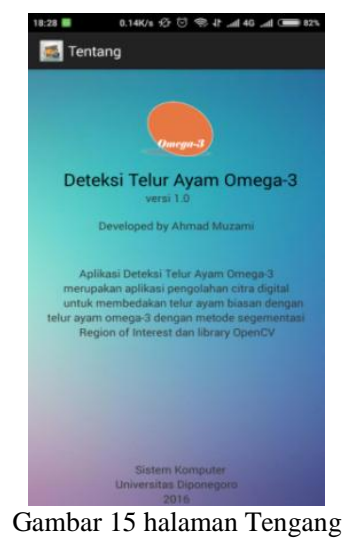

\section{B. Hasil Penelitian dan Pembahasan}

Pelatihan terhadap beberapa sampel data citra telur yang sudah dikumpulkan berdasarkan dua kriteria yaitu citra telur ayam biasa dan citra telur ayam omega-3. Sampel yang digunakan untuk pelatiahan sistem berjumlah 20 data citra telur.

Tahap pertama dalam penelitian ini adalah akuisisi citra. Akuisisi citra dapat dilakukan dengan dua cara yaitu dengan mengunggah citra melalui media pentimpanan dan pengambilan gambara menggunakan kamera. Citra akuisisi dengan format .jpg dan merupakan citra RGB dikonversi ke dalam bentuk citra aras keabuan. Setelah citra diubah kedalam bentuk citra keabuan kemudian citra diolah dengan menambahkan filter median untuk memperbaiki citra yang akan digunakan untuk proses selanjutnya. Citra keabuan yang sudah diberi filter median diproses mengguanakan ekualisasi histogram untuk mendapatkan citra yang lebih baik dan selanjutnya dilakukan seleksi citra (region of interest) pada area citra kuning telur.

Proses seleksi dilakukan karena citra pada area kuning telur yang akan dilakukan analisis statistik orde pertama yaitu menggunakan parameter mean dan standar deviasi. Nilai parameter mean dan standar deviasi digunakan untuk menentukan hasil akhir proses deteksi citra telur apakah masuk ke dalam kategori telur ayam biasa atau telur ayam omega-3. Hasli ekstraksi ciri citra dengan parameter mean dan standar deviasi ditunjukkan pada tabel 2 .

Tabel 2 data sampel telur dan nilai statistik mean dan standar deviasi

\begin{tabular}{|c|c|c|c|c|}
\hline \multirow[b]{2}{*}{ Data } & \multirow{2}{*}{$\begin{array}{c}\text { Citra } \\
\text { Asli }\end{array}$} & \multirow[b]{2}{*}{ Citra ROI } & \multicolumn{2}{|c|}{ Ekstraksi Ciri } \\
\hline & & & Mean & $\begin{array}{l}\text { Standar } \\
\text { Deviasi }\end{array}$ \\
\hline 1 & & & 13,16 & 31,59 \\
\hline 2 & & & 11,71 & 28,51 \\
\hline 3 & & & 12,51 & 31,15 \\
\hline 4 & & & 7,60 & 28,44 \\
\hline 5 & & & 8,16 & 26,38 \\
\hline 6 & & & 9,30 & 32,61 \\
\hline 7 & & & 9,57 & 30,08 \\
\hline 8 & & & 12,22 & 34,10 \\
\hline 9 & & & 10,45 & 29,15 \\
\hline 10 & & & 11,39 & 31,81 \\
\hline 11 & & & 19,17 & 41,86 \\
\hline 12 & & & 20,90 & 52,76 \\
\hline 13 & & & 21,19 & 48,19 \\
\hline 14 & & & 22,25 & 53,24 \\
\hline
\end{tabular}




\begin{tabular}{|l|l|l|l|l|}
\hline 15 & & & 20,58 & 52,20 \\
\hline 16 & & & 21,23 & 56,34 \\
\hline 17 & & 10,73 & 35,57 \\
\hline 18 & & & 10,64 & 38,92 \\
\hline 19 & & & 16,46 & 45,27 \\
\hline 20 & & & 13,10 & 37,63 \\
\hline
\end{tabular}

Hasil penelitian aplikasi deteksi telur ayam omega-3 menggunakan nilai parameter mean dan standar deviasi menunjukkan nilai yang berbedabeda. Hal ini dapat disebabkan karena pada setiap citra sampel memiliki intensitas keabuan yang berbeda-beda dan salah satu faktor yang menentukan nilai mean dan standar deviasi adalah intensitas keabuan.

20 data citra sampel sebelumnya sudah diketahui kategori kelompoknya yaitu 10 data citra telur ayam biasa dan 10 data citra telur ayam omega-3. Dari 20 data citra sampel didapatkan rentang nilai mean dan standar deviasi seperti ditunjukkan pada tabel 3 .

Tabel 3 Penetapan rentang nilai mean dan standar deviasi

\begin{tabular}{|c|c|c|}
\hline \multirow{2}{*}{$\begin{array}{c}\text { Jenis Telur } \\
\text { Ayam }\end{array}$} & \multicolumn{2}{|c|}{ Rentang Nilai } \\
\cline { 2 - 3 } Biasa & $\begin{array}{c}7,00<\text { Mean } \\
<14,00\end{array}$ & $\begin{array}{c}\text { Standar Deviasi } \\
\text { deviasi }<35,00\end{array}$ \\
\hline \multirow{2}{*}{ Omega-3 } & $\begin{array}{c}14,00 \leq \\
\text { Mean }< \\
24,00\end{array}$ & $\begin{array}{c}35,00 \leq \text { Standar } \\
\text { deviasi } \leq 57,00\end{array}$ \\
\hline
\end{tabular}

Penetapan rentang nilai untuk telur ayam biasa didapat dari nilai mean dan standar deviasi tertinggi yang diperoleh dari sepuluh sampel citra telur biasa yang digunakan sebagai citra pelatihan. Dari sepuluh sampel citra telur biasa nilai mean tertinggi adalah 13,16 dan nilai standar deviasi tertinggi adalah 34,10 . Sedangkan penetapan rentang nilai untuk citra telur ayam omega-3 didapatkan dari nilai mean dan standar deviasi yang tidak lebih rendah dari nilai mean dan standar deviasi pada citra telur ayam biasa. Pada sepuluh sampel citra telur ayam omega-3 dapat diketahui nilai mean terendah adalah 10,64 dan standar deviasi terendah adalah 35,57. Jika pada aplikasi ini pembaacaan nilai mean dan standar deviasi yang keluar nilainya tidak masuk pada rentang nilai diatas maka pada hasil deteksi akan dinyatakan sebagai citra yang tidak dapat diidentifikasi.

Akurasi ketepatan baca merupakan metode yang digunakan untuk menghitung prosentase seberapa besar aplikasi membaca data dengan benar. Untuk menentukan akurasi ketepatan baca digunakan rumus yang ditunjukkan pada persamaan 4.

Akurasi $=100 \%-\frac{\text { Data menyimpang }}{\text { Jumlah data }} \times 100 \%$

Berdasarkan rentang nilai pentuan hasil identifikasi dari dua puluh sampel citra yang digunakan terdapat tiga kesalahan pembacaan Untuk parameter mean yaitu pada data 17, 18, dan 20. Kesalahan pembacaan ini dikarenakan nilai mean pada ketiga data tersebut lebih kecil dari rentang nilai jenis telur ayam omega-3. Dari hasil tersebut akurasi ketepatan baca pada aplikasi Deteksi Kualitas Telur Ayam Omega-3 adalah 85\% yang didapatkan dari :

$$
\text { Akurasi }=100 \%-\frac{3}{20} \times 100 \%=85 \%
$$

\section{Pengujian Metode Region of Interest dengan aplikasi ImageJ \\ Pengujian dilakukan dengan mengambil} nilai-nilai yang akan dihitung, misalnya nilai histogram dan nilai intensitas keabuan. Nilai tersebut didapatkan dari histogram citra yang diambil dari aplikasi ImageJ atau Fiji. Aplikasi ImageJ dapat menampilkan parameter nilai yang dibutuhkan pada tahap pengujian ini. Langkah pertama adalah dengan mengambil citra uji dari media penyimpanan.

\section{Pengujian Citra B1.jpg}

Citra B1.jpg merupakan sampel dari citra telur ayam biasa.Terdapat perbedaaan nilai yang muncul dan histogramnya pada citra terseleksi dengan citra yang belum diseleksi. Dengan semakin sempitnya area perhitungan maka histogram dan nilai parameter lainnya pun ikut mengalami perubahan. Perbedaan tersebut dapat dilihat pada gambar 16 dan gambar 17.

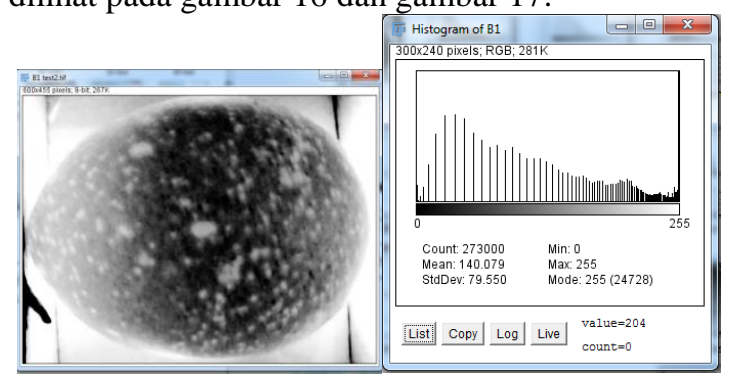

Gambar 16 Citra B1.jpg hasil ekualisasi histogram dan tampilan histogramnya

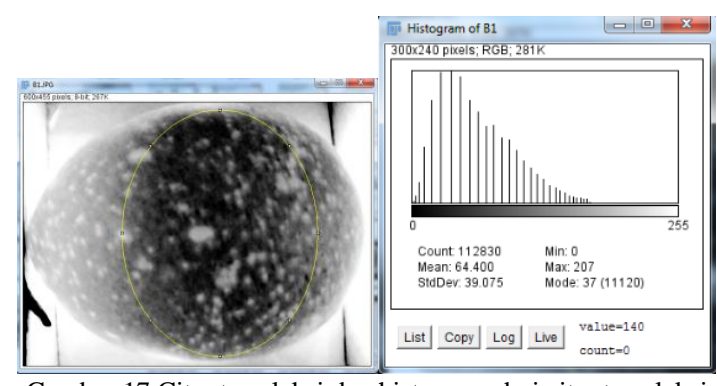

Gambar 17 Citra terseleksi dan histogram dari citra terseleksi 
Pada gambar di atas area ROI yang akan diambil nilainya ditandai dengan garis oval berwarna kuning. Area tersebut dipilih karena area yang akan dijadikan obyek identifikasi adalah area citra kuning.

Nilai histogram didapatkan dari jumlah piksel yang muncul pada tiap intensitas keabuan $n$ dibagi dengan jumlah total piksel pada area ROI. Rumus dari perhitungan histogram ditunjukkan pada persamaan (1). Misalnya untuk mengetahui nilai histogram pada intensitas keabuan ke-0 pada citra B1.jpg bisa dihitung dengan :

$h_{0}=\frac{n_{0}}{n}=\frac{76}{112830}=0,00067$

Perhitungan histogram di atas berlaku untuk pada setiap intensitas keabuan dari intensitas keabuan 0 sampai 255. Jumlah keseluruhan nilai histogram dari intensitas keabuan 0 sampai 255 bernilai 1. Hasil pengujian citra B1.jpg secara lengkap dilampirkan pada lampiran.

Pengujian yang dilakukan pada subbab ini adalah untuk membuktikan metode region of interest pada aplikasi deteksi telur ayam omega-3 dengan perhitungan manual dengan bantuan apikasi imageJ. Perhitungan manual dilakukan menggunakan persamaan mean dan Standar deviasi seperti pada persamaan (2) dan (3). Dari persamaan (2) didapatkan nilai mean pada citra B1.jpg seperti berikut :

$\mu=\sum_{n=0}^{255} f_{n} p\left(f_{n}\right)$

$\mu=\left(f_{0} p\left(f_{0}\right)+f_{1} p\left(f_{1}\right)+\ldots+f_{255} p\left(f_{255}\right)\right)$

$\mu=((0 \times 0,00067)+\cdots+(255 \times 0))=64,4$

Selanjutnya adalah pengujian nilai standar deviasi dari citra B1.jpg. Dari persamaan (3) didapatkan nilai standar deviasi pada citra B1.jpg seperti berikut :

$$
\begin{aligned}
\sigma= & \sqrt{\sum_{n=0}^{N}\left(f_{n}-\mu\right)^{2} p\left(f_{n}\right)} \\
\sigma= & \sqrt{\left(\left(f_{0}-\mu\right)^{2} p\left(f_{0}\right)+\cdots+\left(f_{255}-\mu\right)^{2} p\left(f_{255}\right)\right)} \\
\sigma= & \sqrt{\left((0-64,4)^{2} \cdot 0,00067+\cdots+(255-64,4)^{2} \cdot 0\right)} \\
\sigma= & \sqrt{1526,813}=39,075 \\
& \quad \text { Berdasarkan perhitungan manual yang }
\end{aligned}
$$
digunakan untuk membuktikan metode region of interest didapatkan hasil perhitungan parameter mean dan standar deviasi yang sama dengan perhitungan parameter yang dilakukan pada aplikasi imageJ. Perhitungan mean dan standar deviasi untuk citra B1.jpg pada aplikasi imageJ menunjukkan nilai masing - masing 64,4 dan 39,075 dan hasil yang sama didapatkan dari perhitungan manual.

2. Pengujian Citra om1.jpg

Citra om1.jpg merupakan sampel dari citra telur ayam omega-3. Rumus dari perhitungan histogram ditunjukkan pada persamaan (1). Hasil pengujian citra om1.jpg secara lengkap dilampirkan pada lampiran. Misalnya untuk mengetahui nilai histogram pada intensitas keabuan ke-0 pada citra om1.jpg bisa dihitung dengan :

$h_{0}=\frac{n_{0}}{n}=\frac{151}{152513}=0,00099$
Dari persamaan (2) didapatkan nilai mean pada citra om1.jpg seperti berikut :

$\mu=\sum_{n=0}^{255} f_{n} p\left(f_{n}\right)$

$\mu=\left(f_{0} p\left(f_{0}\right)+f_{1} p\left(f_{1}\right)+\ldots+f_{255} p\left(f_{255}\right)\right)$

$\mu=((0 \times 0,00099)+\cdots+(255 \times 0))=88,151$

Dari persamaan (3) didapatkan nilai standar deviasi pada citra om1.jpg seperti berikut :

$\sigma=\sqrt{\sum_{n=0}^{N}\left(f_{n}-\mu\right)^{2} p f_{n}}$

$\sigma=\sqrt{\left(\left(f_{0}-\mu\right)^{2} p\left(f_{0}\right)+\cdots+\left(f_{255}-\mu\right)^{2} p\left(f_{255}\right)\right)}$

$\sigma=\sqrt{\left((0-88,15)^{2} \cdot 0,00099+\cdots+(255-88,15)^{2} \cdot 0\right)}$

$\sigma=\sqrt{2182,258}=46,715$

Berdasarkan perhitungan manual yang digunakan untuk membuktikan metode region of interest didapatkan hasil perhitungan parameter mean dan standar deviasi yang sama dengan perhitungan parameter yang dilakukan pada aplikasi imageJ. Perhitungan mean dan standar deviasi untuk citra om1.jpg pada aplikasi imageJ menunjukkan nilai masing-masing 88,151 dan 46,715 dan hasil yang sama didapatkan dari perhitungan manual. Hasil perhitungan pada aplikasi imageJ untuk citra om1.jpg ditunjukkan pada gambar 18 .

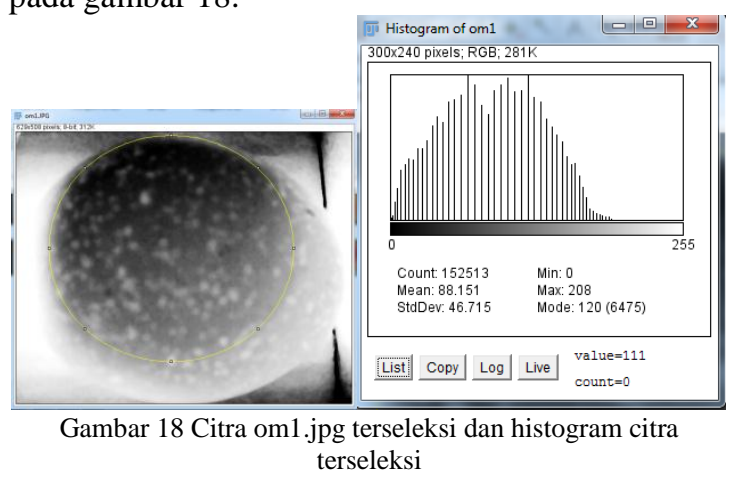

\section{PENUTUP}

\section{A. Kesimpulan}

Berdasarkan hasil pengujian dan analisis aplikasi Deteksi Telur Ayam Omega-3 dapat disimpulkan sebagai berikut :

1. Batasan nilai untuk menentukan hasil deteksi dengan parameter mean dan standar deviasi adalah 7,0 < mean < 14,0 dan 25,0 < standar deviasi < 35,0 untuk telur ayam biasa serta $14,0 \leq$ mean $<24,0$ dan $35,0 \leq$ standar deviasi $\leq 57,0$ untuk telur ayam omega-3.

2. Akurasi tepat baca pada aplikasi ini sebesar $85 \%$ dan memiliki kesalahan pembacaan $15 \%$.

3. Hasil pengujian metode region of interest dengan perhitungan manual menghasilkan nilai yang sama dengan nilai perhitungan pada aplikasi ImageJ sebagai pembanding.

\section{B. Saran}

Berdasarkan hasil pengujian dan analisis pada aplikasi ini terdapat saran untuk pengembangan aplikasi selanjutnya. 
1. Aplikasi deteksi telur omega-3 perlu ditambahkan fitur yang mampu mendeteksi citra telur pada tempat yang terang.

2. Proses seleksi area (Region of Interest) yang dibuat secara otomatis untuk mempermudah pengambilan citra.

\section{DAFTAR PUSTAKA}

[1] Sudaryani, T. (2003). Kualitas Telur. Jakarta: Penebar Swadaya.

[2] Egg Farmers of Canada. Egg Nutrition [Online].Tersedia:http://www.eggs.ca/nutrition /view/1/egg-nutrition

[3] Rahayu, I. H. (2003). Karakteristik Fisik, Komposisi Kimia dan Uji Organoleptik Telur Ayam Merawang Dengan Pemberian Pakan Bersuplemen Omega-3. Jurnal Teknologi dan Industri Pangan, Vol. XIV.
[4] Hermawati, F. (2013). Pengolahan Citra Digital: Konsep dan Teori. Yogyakarta: Penerbit ANDI.

[5] Munir, R. (2006). Aplikasi Image Thresholding Untuk Segmentasi Objek. Seminar Nasional Aplikasi Teknologi Informasi. Yogyakarta: UII.

[6] Yulianto, P. (2008). Peningkatan Citra Untuk Memperjelas Foto Brain CT Scan. Jurnal Ilmiah Semesta Teknika, XI.

[7] Putra, D. (2010). Pengolahan Citra Digital. Yogyakarta: penerbit ANDI.

[8] Oktaviani, R. (2014). Aplikasi Mobile Untuk Identifikasi Fertilitas Telur Dengan Metode Segmentasi Citra Menggunakan Bahasa Java Dan Library Opencv. 